\title{
IL-18 serum concentration is continuously elevated in typical familial Mediterranean fever with M694I mutation and can distinguish atypical type
}

\author{
T Yamazaki ${ }^{1,2^{*}}$, T Shigemura $^{3}$, N Kobayashi ${ }^{3}$, K Honda $^{4}$, M Yazaki $^{5}$, J Masumoto $^{6}$, K Migita $^{7}$, M Tamura $^{1}$, \\ K Agematsu 2,3,4 $^{2}$
}

From 8th International Congress of Familial Mediterranean Fever and Systemic Autoinflammatory Diseases Dresden, Germany. 30 September - 3 October 2015

\section{Objectives}

Familial Mediterranean fever (FMF) can be classified into typical and incomplete/atypical types based on clinical findings and gene analysis, although biomarkers that distinguish typical from atypical FMF have not been unclear.

\section{Methods}

We here investigated the serum cytokine profiles of IL-1 $\beta$, IL-6, IL- 8 , TNF- $\alpha$, IFN- $\gamma$, and IL-18 in FMF compared with those in Kawasaki disease.

\section{Results}

IL-1 $\beta$, IL-6, IL-8, TNF- $\alpha$, and IFN- $\gamma$ were not increased in either type of FMF in the remission state and in controls, and IL- 6 was elevated during attack periods among patients. Serum IL-18 levels were significantly higher in typical FMF patients with M694I MEFV mutation in remission than in controls at the same level as flared Kawasaki disease, which further increased during attack periods. In contrast, IL-18 levels in atypical FMF with P369S-R408Q mutation or in typical FMF without M694I mutation was not increased, in either disease states.

\section{Conclusion}

Thus, serum IL-18 levels at attack increase more than in remission, and that are an excellent marker to distinguish between the two types of FMF.

${ }^{1}$ Saitama Medical Center, Saitama Medical University, Pediatrics, Kawagoe, Japan

Full list of author information is available at the end of the article

\section{Authors' details}

${ }^{1}$ Saitama Medical Center, Saitama Medical University, Pediatrics, Kawagoe, Japan. ${ }^{2}$ Shinshu University Graduate School of Medicine, Infection and Host Defense, Matsumoto, Japan. ${ }^{3}$ Shinshu University School of Medicine, Pediatrics, Matsumoto, Japan. ${ }^{4}$ Northern Yokohama Hospital, Showa University, Children's Medical Center, Yokohama, Japan. ${ }^{5}$ Shinshu University School of Medicine, Internal Medicine, Matsumoto, Japan. ${ }^{6}$ Ehime University Graduate School of Medicine and Ehime Proteo-medicine Research Center, Pathology, Toon, Japan. ${ }^{7}$ Nagasaki Medical Center, Clinical Research Center, Omura, Japan.

Published: 28 September 2015

doi:10.1186/1546-0096-13-S1-P80

Cite this article as: Yamazaki et al.: IL-18 serum concentration is continuously elevated in typical familial Mediterranean fever with M694I mutation and can distinguish atypical type. Pediatric Rheumatology 2015 13(Suppl 1):P80.
Submit your next manuscript to BioMed Central and take full advantage of:

- Convenient online submission

- Thorough peer review

- No space constraints or color figure charges

- Immediate publication on acceptance

- Inclusion in PubMed, CAS, Scopus and Google Scholar

- Research which is freely available for redistribution
() Biomed Central 